\title{
Synthetic fibre granuloma of the conjunctiva
}

\author{
ST Mak *, YH Lui, Kenneth KW Li
}

\section{A B S T R A C T}

Synthetic fibre granuloma of the conjunctiva, sometimes known as 'teddy bear granuloma', results from granulomatous foreign body reaction of the conjunctiva to synthetic fibres. It is often an incidental finding, most commonly found in children, is unilateral, and occurs in the lower eyelid. We present here, what we believe is the first reported case of synthetic fibre conjunctival granuloma in Hong Kong, together with a review of the condition. An awareness of this clinical entity allows early and accurate diagnosis and early treatment.

\author{
Hong Kong Med J 2015;21:77-9 \\ DOI: $10.12809 / \mathrm{hkmj} 144210$ \\ ${ }^{1,2}$ ST Mak *, FRCSEd (Ophth), FHKAM (Ophthalmology) \\ ${ }^{3}$ YH Lui \#, FRCPA, FHKCPath \\ ${ }^{1,2}$ KKW Li, FRCS (Ed), FHKAM (Ophthalmology) \\ ${ }^{1}$ Department of Ophthalmology, United Christian Hospital, Kwun Tong, \\ Hong Kong \\ 2 Department of Ophthalmology, LKS Faculty of Medicine, The University \\ of Hong Kong, Pokfulam, Hong Kong \\ ${ }^{3}$ Department of Pathology, United Christian Hospital, Kwun Tong, Hong \\ Kong \\ \# YH Lui is now with the Department of Clinical Pathology, Pamela Youde \\ Nethersole Eastern Hospital, Chai Wan, Hong Kong \\ * Corresponding author: dr.makst@gmail.com
}

\section{Introduction}

Synthetic fibre granuloma of the conjunctiva, sometimes known as 'teddy bear granuloma', was first described by Weinberg et al in $1984 .{ }^{1}$ It is a rare granulomatous foreign body reaction of the conjunctiva to synthetic fibres. It occurs most commonly in children, and usually presents as a unilateral, inferior conjunctival mass of the lower eyelid. The lesion is known as 'teddy bear granuloma' because some cases were caused by materials used in stuffed toy animals. ${ }^{2}$

Seventeen cases of conjunctival synthetic fibre 'teddy bear granuloma' have been reported in the literature. To the best of our knowledge, this is the first reported case of this condition in Hong Kong.

\section{Case report}

A 7-year-old girl with good health presented to the ophthalmology clinic of United Christian Hospital, Hong Kong, in December 2012 with a left lower eyelid conjunctival mass for 1 month. There was no history of trauma. It was an incidental finding by the girl's mother and the girl did not complain of any pain or discomfort. There was no change in visual acuity.

Examination showed a $3.5 \mathrm{~mm} \mathrm{x} 1.5 \mathrm{~mm}$ conjunctival mass in the inferior fornix of her left lower eyelid (Fig a). It was embedded with a bunch of hair-like material. The lesion prolapsed easily with gentle pressure over the lower eyelid but could not be removed during slit-lamp examination. The rest of her ophthalmological examination was normal.
The girl's mother was very keen on removal of the mass. Excisional biopsy of the mass was performed under general anaesthesia. The mass was excised and sent for histopathological analysis.

Microscopic examination revealed a piece of conjunctival mucosa with stromal granulation tissue showing heavy chronic inflammation, mild activity, and aggregates of foreign body consistent with synthetic fibres, associated with giant cell reaction (Figs b to $d$ ). The fibres were refractile and colourless. In another section, scanty hair was seen in the stroma. The picture was compatible with a diagnosis of synthetic fibre granuloma of the conjunctiva.

Postoperatively, the wound healed well and there was no recurrence of the lesion at 1.5 years after excision.

\section{Discussion}

Protective mechanisms of the eye including blinking and tearing normally remove any foreign body that comes into contact with the ocular surface. Occasionally, foreign body may be retained in the eyelid fornix, encapsulated by mucous, embedded in the underlying stroma, and, subsequently, induces a local inflammatory response. ${ }^{2}$ Synthetic fibre granuloma of the conjunctiva occurs when synthetic fibres are inoculated in the conjunctiva of the eyelid fornix leading to an inflammatory reaction. The lesion is also commonly known as 'teddy bear granuloma' because some cases were caused by materials used in stuffed toy animals. ${ }^{2}$ Various other objects have been suggested as the source of the lesion, including 


\section{合成纖維異物致結膜肉芽腫}

\section{麥兆婷、呂潤開、李啟煌}

合成纖維異物致結膜肉芽腫, 有時被稱為「泰迪熊肉芽腫」, 是由於 合成纖維類異物留在結膜囊內形成肉芽腫的結果。這種現象往往是被 偶然發現; 常見於兒童, 多數為單側, 並發生在下瞼位置。本文描述 一宗合成纖維異物致結膜肉芽腫的病例並回顧其病情。這宗相信是香 港首個文獻記載病例。了解其臨床症狀能及早為病人作出準確的診 斷, 繼而及時施予治療。 blankets, beddings, and pullover sweaters..$^{2-4}$

The majority of patients were brought in by parents or caretakers who identified a mass in the child's eyelid. The patients were usually asymptomatic, without a history of trauma. Affected children may rarely present with symptoms of ocular irritation and foreign body sensation. ${ }^{5}$ Synthetic fibre conjunctival granuloma is usually unilateral, and mainly occurs in the inferior eyelid fornix, except in one reported case where it presented superiorly. ${ }^{1}$

Differential diagnoses of synthetic fibre conjunctival granuloma include chalazion, pyogenic granuloma, papillary hyperplasia, sarcoidosis, dermoid, or neoplasm including rhabdomyosarcoma. ${ }^{2,6,7}$ It has been proposed that the most reliable clinical sign to suggest this diagnosis was the presence of a unilateral inferior conjunctival mass in a child or adolescent. ${ }^{2}$ In addition, the histological features of synthetic fibre conjunctival granuloma are characteristic and diagnostic. Microscopic examination reveals granulomatous inflammatory cell response with lymphocytes, plasma cells and eosinophils, and foreign-body giant cells surrounding the exogenous synthetic fibres. ${ }^{4,8}$

Treatment of synthetic fibre conjunctival granuloma involves surgical removal of the foreign body and excision of the granuloma. ${ }^{2}$ Should the granuloma present early and the patient be compliant, it has been suggested to remove the lesion during slit-lamp examination under topical
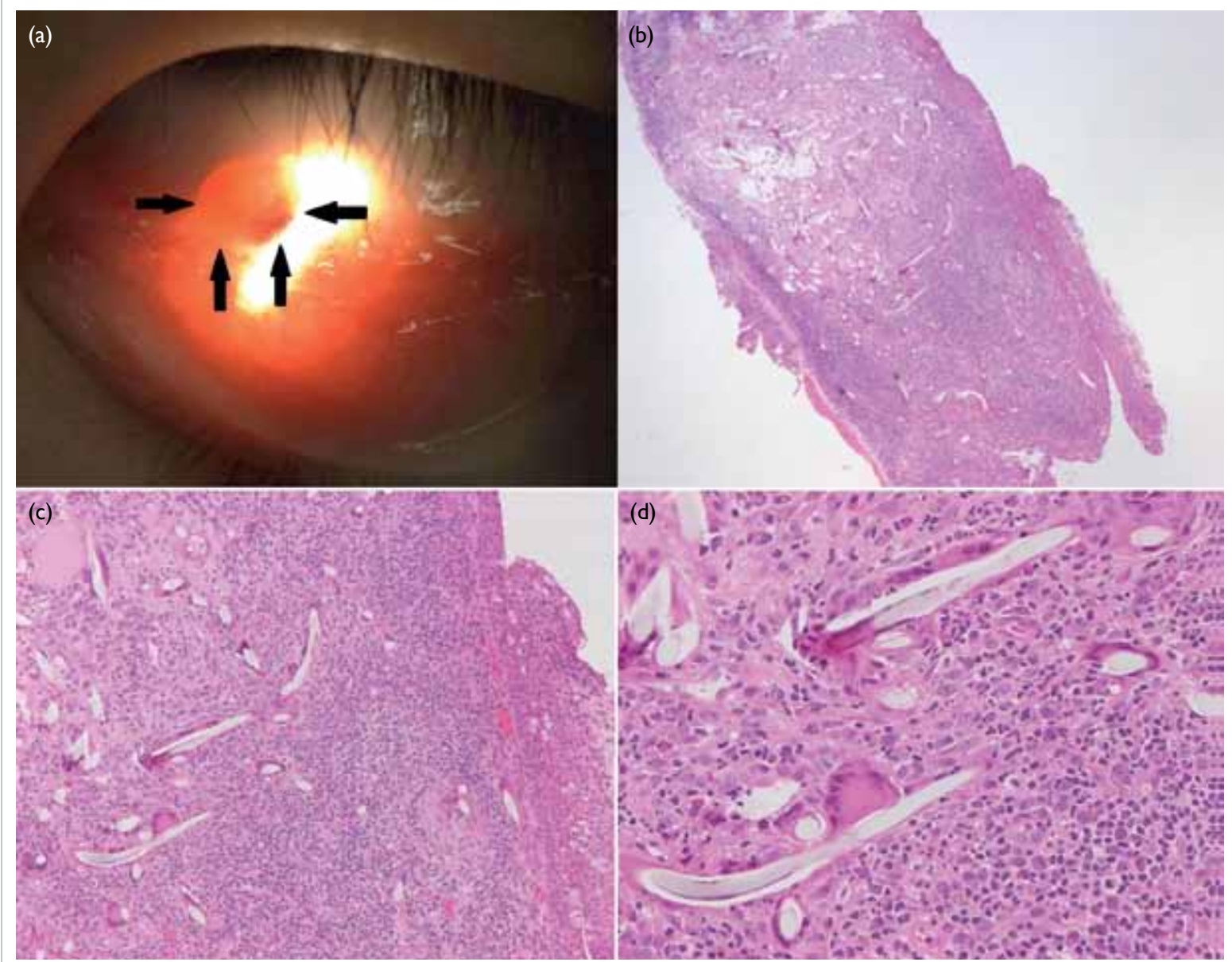

FIG. (a) A slit-lamp photograph showing a conjunctival mass (arrows) in the inferior fornix of the left lower eyelid. Histopathological sections of the biopsy specimen: (b) conjunctival mucosal lesion contains numerous synthetic fibres in an inflamed background (H\&E; original magnification, $x$ 40); (c) synthetic fibres associated with foreign-body giant cell reaction are seen in an inflamed background (H\&E; original magnification, $x$ 100); (d) the synthetic fibres are refractile, colourless, and surrounded by histiocytic giant cells (H\&E; original magnification, $x 200$ ) 
anaesthesia with minimal bleeding and discomfort. ${ }^{9}$ However, since the granuloma is usually present for a long duration before being noticed, the lesion could be deeply embedded. As a result, excision in the operating theatre under general anaesthesia is often needed, particularly when patients are very young and anxious. Prognosis following surgical excision is excellent. $^{6}$

Although the entity of synthetic fibre conjunctival granuloma was recognised more than two decades ago, clinicians, including ophthalmologists and pathologists, are unfamiliar with this condition. ${ }^{4}$ While the number of reports in the literature is limited, accurate reporting may actually reveal a higher incidence of this entity. ${ }^{9}$ An awareness of this condition will allow early and accurate diagnosis and treatment, which subsequently spare the risks and expense associated with general anaesthesia. ${ }^{3}$

\section{Declaration}

No conflicts of interests were declared by authors.

\section{References}

1. Weinberg JC, Eagle RC Jr, Font RL, Streeten BW,
Hidayat A, Morris DA. Conjunctival synthetic fiber granuloma. A lesion that resembles conjunctivitis nodosa. Ophthalmology 1984;91:867-72.

2. Schmack I, Kang SJ, Grossniklaus HE, Lambert SR. Conjunctival granulomas caused by synthetic fibers: report of two cases and review of literature. J AAPOS 2005;9:56771.

3. Enzenauer RW, Speers WC. Teddy bear granuloma of the conjunctiva. J Pediatr Ophthalmol Strabismus 2002;39:468.

4. Ferry AP. Synthetic fiber granuloma. 'Teddy bear' granuloma of the conjunctiva. Arch Ophthalmol 1994;112:1339-41.

5. Farooq MK, Prause JU, Heegaard S. Synthetic fiber from a teddy bear causing keratitis and conjunctival granuloma: case report. BMC Ophthalmol 2011;11:17.

6. Shields JA, Augsburger JJ, Stechschulte J, Repka M. Synthetic fiber granuloma of the conjunctiva. Am J Ophthalmol 1985;99:598-600.

7. Lueder GT. Synthetic fiber granuloma. Arch Ophthalmol 1995;113:848-9.

8. Batta B, Robin A, George JL, Angioi K. "Teddy bear granuloma", a rare condition: a case report of a 3-year-old child [in French]. J Fr Ophtalmol 2012;35:117-20.

9. Resnick SC, Schainker BA, Ortiz JM. Conjunctival synthetic and nonsynthetic fiber granulomas. Cornea 1991;10:59-62. 